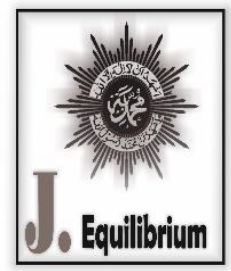

Prodi Pendidikan Sosiologi

Equilibrium: Jurnal Pendidikan

Vol.VIII.Issu 1. Januari-Juni 2020
Prodi Pendidikan Sosiologi

Sosiologi

http://journal.unismuh.ac.id/index.php/equilibrium

\title{
Evaluasi Program Praktek Dunia Kerja Fakultas Teknik Komputer Universitas Cokroaminoto Palopo Tahun Akademik 2018/2019
}

\author{
Abdul Zahir ${ }^{1}$, Andi Rosman ${ }^{2}$, Supriadi ${ }^{3}$ \\ ${ }^{1}$ Program Studi Informatika, Universitas Cokroaminoto Palopo \\ Email: abdulzahir86@gmail.com \\ ${ }^{2}$ Program Studi Informatika, Universitas Cokroaminoto Palopo \\ Email: andirosman37@gmail.com \\ ${ }^{3}$ Program Studi Informatika, Universitas Cokroaminoto Palopo \\ Email: supriadi89@gmail.com
}

\begin{abstract}
Research on Program Evaluation of the Work World Practice (PDK) ofComputer Engineering Faculty, Cokroaminoto Palopo University AcademicYear 2018/2019 aims to evaluate the implementation of the PDK with theCIPP model approach. The research method is evaluation research with a qualitative description approach. This research was shown to evaluate theWork World Practice (PDK) program in Academic Year 2018/2019 organizedby the Computer Engineering Faculty of Cokroaminoto Palopo University(FTKOM UNCP) with the CIPP evaluation model. This research was held inFTKOM UNCP and 65 PDK locations. This research was conducted inFebruary to April 2019. The results of the research showed: 1) in termsofcontext, the implementation of PDK has been done in accordance with theobjectives and vision and mission of higher education (university, faculty andstudy program), 2) in terms of input; PDK has been implementedinaccordance with the curriculum and procedures that have been determined,the administrator has managed the PDK well because it is supported byfacilities and infrastructure and sufficient budget, and students who becomeparticipants have fulfilled the PDK requirements, 3) in term of process, goodcooperation between institution and agency of PDK run well so that theimplementation of the PDK went well and finished on time, 4) in terms ofproducts, there were students' enhancement in cognition, affection andpsychomotor after implementing it and the goals were achieved well.
\end{abstract}

Keywords : Program Evaluation, Work World Practice, CIPP

Abstrak. Penelitian Evaluasi Program Praktik Kerja Dunia (PDK) Fakultas Teknik Komputer Universitas Cokroaminoto Palopo Tahun Akademik 2018/2019 bertujuan untuk mengevaluasi pelaksanaan PDK dengan pendekatan model CIPP. Jenis penelitian yang digunakan dalam penelitian ini adalah penelitian evaluasi dengan pendekatan deskripsi kualitatif. Penelitian ini ditunjukkan untuk mengevaluasi program Praktik Kerja Tahun Akademik (2018/2019) yang dilaksanakan oleh Fakultas Teknik Komputer Universitas Cokroaminoto Palopo (FTKOM UNCP) dengan model evaluasi CIPP. Penelitian ini dilakukan di FTKOM UNCP dan di 65 lokasi implementasi PDK.Penelitian ini dilakukan sepanjang Februari hingga April 2019. Hasil penelitian menunjukkan: 1) dari segi konteks, pelaksanaan PDK telah berjalan sesuai dengan tujuan dan visi dan misi pendidikan tinggi (universitas, fakultas dan program studi ), 2) dalam hal input; PDK telah dilaksanakan sesuai dengan kurikulum dan prosedur yang telah ditentukan, pengelola telah mengelola PDK dengan baik karena didukung oleh sarana dan prasarana serta anggaran yang memadai, dan mahasiswa yang menjadi peserta telah memenuhi persyaratan pelaksanaan PDK, 3) dari proses, kerja sama yang baik antara institusi dan tempat PDK berjalan dengan baik sehingga implementasi PDK berjalan dengan baik dan pelaksanaan PDK tepat waktu, 4) dalam hal produk, ada peningkatan dalam kognisi, afeksi dan psikomotor siswa setelah menerapkan tujuan PDK dan nilai mahasiswa rata-rata baik. 


\section{PENDAHULUAN}

Ada banyak faktor yang mengakibatkan rendahnya kualitas pendidikan di Indonesia, salah satunya adalah ketidakmampuan mengelola proses pembelajaran di setiap mata pelajaran di sekolah atau mata kuliah di perguruan tinggi. Salah satu mata kuliah yang ada di perguruan tinggi yang mesti dikelola dengan baik adalah mata kuliah yang berkaitan dengan peningkatan aspek psikomotorik mahasiswa, yakni mata kuliah praktik yang dilangsungkan di luar kampus.Penyelenggaraan mata kuliah praktik yang dilaksanakan di luar kampus atau di dunia kerja (dunia usaha dan dunia industri) dimaksudkan untuk menghasilkan mahasiswa yang profesional dan kompoten.

Fakultas Teknik Komputer Universitas Cokroaminoto Palopo sebagai salah satu institusi penyelenggara pendidikan keteknikan dibidang komputer sangat menyadari arti penting mata kuliah praktik ini.Mata kuliah ini kemudian dinamakan Praktik Dunia Kerja.Di beberapa kampus atau penyelenggara pendidikan teknik lainnya menyebutnya mata kuliah praktik industri, seperti di FT UNY dan FT UNM.Fakultas Teknik Komputer Universitas Cokroaminoto Palopo (FTKOM UNCP) sebagai penyelenggara pendidikan keteknikan di bidang teknik informatika mempunyai misi dalam menyelenggarakan pendidikan dan pengajaran untuk menghasilkan sumber daya yang unggul dan berkarakter.Pencapaian misi sudak terintegrasi dalam kurikulum dan salah satu jabaran kurikulum tersebut terdapat dalam mata kuliah Praktek Dunia Kerja yang wajib diprogramkan oleh mahasiswa semester VI (enam).

Praktek Dunia Kerja atau yang disingkat PDK merupakan nama program sekaligusmatakuliahdenganbobot 4 sks yang dilaksanakan di FTKOM UNCPsejak tahun Akademik 2011/2012 (sebelumnya hanya berbobot 0 sks).Kegiatan PDK sudah dilaksanakan selama kurang lebih 7 (tujuh) tahun berturut-turut dan kegiatan saat ini merupakan kegiatan yang ketujuh kalinya dilaksanakan pada FTKOM.PDK yang sudah dilaksanakan tujuh kali dikelola langsung oleh pihak fakultas.Seiring berlakunya pembayaran sumbangan pembiayaan pendidikan (SPP) dalam bentuk UKT (Uang Kuliah Tetap) untuk mahasiswa yang masuk di Universitas Cokroaminoto Palopo sejak tahun 2016 (tahun akademik 2016/2017), maka pada tahun ini (2018/2019) pelaksanaan PDK dikelola oleh badan pengelola yang bertanggungjawab langsung kepada pimpinan universitas.Pengelolaan PDK tahun ini mengalami banyak hal perubahan, baik dari konteks pelaksanaan, input-nya, prosesnya hingga product-nya.

Pendekatan cara mengevaluasinnya menggunakan pendekatan evaluasi ala CIPP. Konsep evaluasi model CIPP (Context, Input, Process and Product) pertama kali dikenalkan oleh Stufflebeam (1985:153) pada tahun 1965 sebagai hasil usahanya mengevaluasi ESEA (the Elementary and Secondary Education Act). Menurut Madaus, Scriven, dan Stufflebeam (1993:) dalam Arikunto dan Safruddin (2009), tujuan penting evaluasi model ini adalah untuk memperbaiki. Evaluasi model Stufflebeam terdiri dari empat dimensi, yaitu: context, input, process, dan product, sehingga model evaluasinya diberi nama CIPP. Evaluasi model ini bermaksud membandingkan kinerja dari berbagai dimensi program dengan sejumlah kriteria tertentu.Pengelolaan PDK dengan mekanisme yang baru perlu dievaluasi pelaksanaannya. PDK sebagai sebuah program akan dievaluasi mulai dari segi konteks, masukan, proses dan keluarannya, maka diperlukan penelitian mendalam tentang "Evaluasi Program Praktek Dunia Kerja Fakultas Teknik Universitas Cokroaminoto Palopo Tahun Akademik 2018/2019".

\section{METODE PENELITIAN}

Jenis penelitian yang digunakan dalam penelitian ini adalah penelitian evaluasi dengan pedekatan deskripsi kualitatif. Penelitian ini ditunjukkan untuk mengevaluasi program Praktek Dunia Kerja (PDK) tahun akademik 2018/2019 yang dilaksanakan oleh Fakultas Teknik Komputer Universitas Cokroaminoto Palopo (FTKOM UNCP) dengan model evaluasi CIPP. Penelitian ini dilaksanakan di Fakultas Teknik Komputer Universitas Cokroaminoto Palopo dan tempat pelaksanaan PDK yang tersebar di Kota Palopo, Kabupaten Luwu, Kabupaten Luwu Utara dan Kabupaten Luwu 
Timur yang totalnya mencapai 80 instansi (dunia usaha dan dan dunia industri) yang diikuti sebanyak 369 mahasiswa. Penelitian ini dilakukan sepanjang Januari hingga Juli 2019.

Data dalam penelitian ini dikumpulkan dengan menggunakan banyak teknik yakni observasi, wawancara, angket dan dokumentasi. Data atau informasi yang diperoleh dalam penelitian evaluasi ini berasal dari empat sumber yakni: 1) dokumen yang merupakan syarat administrasi dari suatu program, 2) angket (kuesioner) yang disebarkan kepada dua narasumber (mahasiswa dan pembimbing lapangan), dan 3) wawancara terhadap narasumber (pimpinan fakultas, ketua prodi, pengelola PDK, dosen pembimbing, pembimbing lapangan dan mahasiswa), dan 4) observasi dilakukan dengan mengamati tempat penelitian secara langsung (UNCP dan DUDI).

Data yang diperoleh dengan menggunakan dokumen berupa angka-angka atau simbol-simbol yang menunjuk peringkat kondisi objek yang ditelaah. Data bersumber dari SOP, syarat administrasi, daftar mahasiswa, SK Pengelola, SK Dosen Pembimbing, nilai, MoU, foto kegiatan dan dokumen relevan lainnya. Data yang diperoleh dengan menggunakan angket (kuesioner) maka data yang diperoleh berupa centangan atau tanda checklist $(V)$ pada pilihan-pilihan, lingkaran-lingkaran pada angka atau huruf/kata yang disediakan dalam instrumen, atau kalimat-kalimat jawaban yang sifatnya kualitatif. Data ini didapatkan dari respon dari pembimbing lapangan dan mahasiswa untuk mengukur aspek proses dan produknya.

Data yang diperoleh dengan wawancara, wujud data yang diperoleh berbentuk centangan, lingkaran, dan kalimat jawaban yang diberikan oleh responden (interviewee) dan dicatat oleh pengumpul data atau peneliti/evaluator. Wawancara ini dilakukan pada pimpinan fakultas, pimpinan program studi, pengelola PDK, pembimbing lapangan, dosen pembimbing, dan mahasiswa. Datanya akan mengungkapkan aspek konteks, masukan, proses dan produknya. Data yang diperoleh dari observasi berupa centangan atau tanda checklist $(V)$ pada pilihan-pilihan, lingkaran-lingkaran pada angka atau huruf/kata yang disediakan dalam instrumen.Observasi dilakukan di Kampus 1 UNCP dan Tempat PDK. Di kampus UNCP mengungkapkan kondisi sarana dan prasarana (aspek input), sedangkan di Tempat PDK mengungkapkan data terkait dengan kondisi tempat PDK (aspek input) dan pelaksanaan PDK (aspek proses).Data-data mentah di atas berikutnya disajikan/diolah untuk memudahkan pemaknaan/penafsiran terhadap data itu sendiri sehingga proses analisisnya menjadi lebih reliabel dan valid. Penyajian/pengolahan data mentah tersebut dilakukan melalui tiga tahapan, yakni tabulasi data, analisis data dan triangulasi data.

\section{HASIL DAN PEMBAHASAN}

Hasil dari penelitian evaluasi ini disusun berdasarkan komponen yang diukur. Secara sistematis hasil penelitian akan mengungkapkan hasil pengukuran pada aspek konteks, masukan, proses dan produk.

\section{Aspek Konteks}

Komponen konteks PDK meliputi profil PDK yakni tujuan PDK, kesesuaian tujuan PDK dengan visi dan misi institusi, ketersediaan pembimbing, jumlah mahasiswa, ketersediaan sarana belajar mengajar, jadwal perkuliahan, dan konsep kerjasama antara kampus dengan dunia industri.Hasil observasi, wawancara dan dokumentasi di atas memperlihatkan bahwa tujuan pelaksanaan PDK sangat sesuai dengan visi, misi dan tujuan dari program studi teknik informatika, fakultas teknik komputer dan universitas cokroaminoto palopo.Bahkan bisa disimpulkan bahwa tujuan PDK terimplementasi dan telah berjalan sesuai dengan tujuan dan visi dan misi pendidikan tinggi (universitas, fakultas dan program studi).

Jumlah pembimbing berdasarkan hasil observasi dan wawancara ditemukan bahwa jumlah pembimbing disesuaikan dengan jumlah tempat praktek, wilayah tempat praktek dan jumlah dosen yang memenuhi syarat menjadi pembimbing. Penetapan jumlah pembimbing dilakukan berdasarkan hasil mufakat antara pengelola PDK dengan pimpinan fakulas dan program studi. Penetapan jumlah pembimbing sudah berjalan sangat tepat dan dirumuskan dengan baik. 
Jumlah mahasiswa yang akan mengikuti PDK didasarkan pada jumlah mahasiswa yang telah memprogramkan mata kuliah dan telah memenuhi syarat yang telah ditetapkan oleh pengelola. Jumlah mahasiswa memprogramkan PDK belum tentu diikutkan melaksanakan PDK jika ada syarat yang ditetapkan oleh pengelola PDK tidak terpenuhi. Data penelitian diperoleh dengan pendekatan wawancara dan dokumentasi yang menunjukkan bahwa jumlah mahasiswa yang melaksanakan PDK tahun ini lebih banyak dibanding tahun sebelumnya dan penetapan jumlah mahasiswa yang ikut PDK sudah berjalan sesuai dengan baik.

Fakultas Teknik Komputer sudah menyiapkan sarana belajar yang memadai untuk mempersiapkan mahasiswa yang siap melaksanakan PDK dengan baik.Hasil observasi, wawancara dan dokumentasi memperlihatkan adanya ruang kuliah, laboratorium, bengkel dan perpustakaan yang sangat layak merupakan unjuk kerja yang baik. Hal ini pula ditunjang dengan jadwal perkuliahan yang disusun secara sistematis dan terencana dengan baik.Hal ini dibuktikan pelaksanaan PDK ditahun sebelumnya sesuai dengan waktunya.

Pelaksanaan PDK yang melibatkan dunia usaha dan dunia industri mesti tertata dengan baik sehingga pelaksanaan PDK dapat berjalan sesuai tujuannya.Berdasarkan hasil wawancara dan dokumentasi, aspek konteks berkaitan dengan konsep kerjasama antara kampus dengan dunia usaha dan dunia industri memperlihatkan performa yang baik.Banyak tempat PDK telah menjalin kerjasama dengan kampus yang dibuktikan dengan banyaknya nota kesepahaman (momorandum of understanding/ MoU).

\section{Aspek Masukan}

Subjek kajian dalam aspek masukan dalam penelitian ini meliputi kurikulum, prosedur, pengelola PDK, dosen pembimbing, mahasiswa, penentuan waktu dan tempat PDK, sarana dan prasarana, dan dana dan anggaran.Kurikulum yang berkaitan dengan PDK sejak FTKOM berdiri sejak tahun 2005 sudah dua kali mengalami perubahan.Kurikulum PDK sejak tahun akademik 2011/2011 hingga tahun akademik 2014/2015 hanya berbobot 0 sks. Karena adanya perubahan kurikulum yang didasarkan pada KKNI (Kerangka Kualifikasi Nasional Indonesia) yang dilakukan pada tahun 2015 dan kemudian diterapkan di tahun akademik 2015/2016, PDK pun mengalami perubahan dan diberi bobot 4 SKS.

PDK dengan kode matakuliah KM005 merupakan matakuliah yang bisa diprogramkan mahasiswa pada semester VI (genap) disetiap tahun akademik.Matakuliah prasayarat yang wajib dilulusi untuk memprogramkan matakuliah PDK adalah Pengetahuan Komputer (UCO03), Perangkat Lunak Aplikasi (KM003) dan Etika Profesi Teknik Informatika (KM002). PDK merupakan matakuliah wajib (bukan pilihan), berarti setiap mahasiswa program studi teknik informatika wajib memprogramkan dan lulus pada matakuliah ini. Pelaksanaan PDK tahun akademik 2018/2019 sudah sangat sesuai dengan kurikulum.

Prosedur pelaksanaan PDK sudah ter-dokumentasi dan ter-implementasi dengan baik dikarenakan PDK sudah dilaksanakan berkali-kali dan ada standar operasional prosedur telah ditetapkan. Prosedur meliputi prosedur pembentukan pengelola PDK, prosedur penetapan dosen pembimbing, prosedur pendaftaran PDK, prosedur keuangan DPK, prosedur pelaksanaan PDK (pengantaran, monitoring dan penarikan), prosedur pembekalan mahasiswa dan dosen pembimbing, prosedur laporan dan penilaian, dan prosedur penyusunan laporan akhir.

Pengelola PDK adalah dosen program studi teknik informatika yang diberi tanggung jawab bertugas untuk mengelola PDK. Penetapan pengelola PDK mengikuti mekanisme yang sama dengan pengelola program magang dan kerja lapang yang ada di universitas. Progam studi bersama fakultas mengusulkan nama dosen yang ingin dijadikan pengelola dan kemudian melakukan rapat bersama dosen yang diusulkan. Dosen yang diusulkan berjumlah lima orang dosen. Dalam rapat bersama diputuskan siapa yang menjadi ketua pengelola beserta strukturnya lain. Lima orang yang tersebut diajukan namanya ke universitas untuk disetujui menjadi pengelola dan kemudian diterbitkan surat keterangan oleh fakultas sebagai bentuk legalitas pengelola PDK (SK No. 002/FTKOM-UNCP/XI/2018).

Hasil observasi dan wawancara memperlihatkan bahwa pengelola PDK yang jumlahnya sangat minim berhasil melaksanakan tugas pokok dan fungsinya.Tahapan PDK terlaksana dengan baik dan sesuai dengan waktu yang ditetapkan. Dukungan moril dari pihak fakultas menjadi motor penggerak kerja optimal pengelola PDK. 
Dosen pembimbing adalah dosen tetap yayasan yang ada dalam lingkup program studi teknik informatika.Dosen pembimbing ditentukan oleh pihak fakultas dan PDK tahun akademik 2018/2019 melibatkan 14 dosen pembimbing.Dosen pembimbing yang ditentukan didasarkan pada prosedur yang telah ada.Dosen pembimbing yang telah ditunjuk berdasarkan SK No. 002/FTKOM-UNCP/XI/2018 akan diberikan pembekalan berkaitan dengan proses pengantaran mahasiswa ke tempat PDK, proses monitoring PDK, proses penarikan mahasiswa ke tempat PDK, penyusunan laporan, dan penilaian. Hasil observasi dan wawancara menunjukkan dosen pembimbing melaksanakan tugas pokok dan fungsinya dengan sangat baik.

Mahasiswa yang mengikuti PDK tahun akademik 2018/2019 sebanyak 369 orang terdiri dari mahasiswa angkatan 2016 sebanyak 366 orang dan angkatan 2015 sebanyak 3 orang. Mahasiswa angkatan 2016 merupakan mahasiswa yang baru menuntaskan semester ganjil tahun akademik 2018/2019 dan baru pula memprogramkan matakuliah PDK, sedangkan mahasiswa angkatan 2015 yang ikut PDK adalah mahasiswa yang tidak memprogramkan PDK pada tahun akademik sebelumnya.

Waktu PDK didasarkan pada kalender akademik dan tempat PDK didasarkan pada hasil penjajakan dan kerjasama yang dilakukan oleh pengelola PDK dan FTKOM.Kegiatan PDK yang dimulai dengan penjajakan tempat PDK dimulai sejak 26 November 2018 yang dilaksanakan oleh pengelola PDK. Sedangkan pelaksanaan PDK dimana mahasiswa sudah memulai PDK dilaksanakan pada tanggal 21 Januari 2019 dan berakhirnya ditandai dengan penarikan mahasiswa yang dilaksanakan pada tanggal 9 Maret 2019. Secara keseluruhan mahasiswa melaksanakan PDK selama 7 minggu (21 Januari 2019 - 9 Maret 2019). Kalender akademik tahun akademik 2018/2019 pada tanggal 21 Januari hingga 18 Februari 2019 merupakan waktu tidak adanya kegiatan akademik (libur) untuk mahasiswa sehingga waktu pelaksanaan PDK diwaktu itu sudah tepat. 18 Februari 2019 merupakan hari pertama kegaiatan akademik semester genap tahun akademik 2018/2019 dan itu berarti mahasiswa PDK tidak mengikuti proses perkuliahan selama 3 minggu.

Sarana dan prasarana penunjang PDK dan pengelolaan PDK berdasarkan hasil observasi, wawancara dan dokumentasi terkategori sangat baik. Ruang kuliah untuk proses pembelajaran sangat memadai. Ruang kuliah di Gedung A kampus 1 merupakan ruang kuliah yang dikhususkan untuk program studi teknik informatika ditambah 2 ruang kelas di Gedung B. Dengan selesainya pembangunan gedung baru, maka prasarana ruang kelas semakin bertambah dan semakin bagus untuk proses pembelajaran. Sudah ada 2 ruang kelas yang dilengkapi TV LED dan semua ruang kelas sudah dilengkapi kipas angin untuk meningkatkan kenyamanan proses pembelajaran. Laboratorium yang berjumlah 6 meliputi laboratorium rekayasa perangkat lunak, laboratorium hardware, laboratorium jaringan komputer, laboratorium bengkel, laboratorium multimedia dan laboratorium sistem informasi geografis.Semua laboratorium dilengkapi sistem pendingin dan komputer yang sangat memadai.Perpustakaan untuk menunjang pembelajaran pun sangat mencukupi dikarenakan ada 3 perpustakaan dikelola universitas dan 1 perpustakaan yang dikelola oleh program studi teknik informatika.

\section{Aspek Proses}

Subjek kajian dalam aspek proses dalam penelitian ini meliputi proses persiapan PDK (proses pendaftaran PDK, proses pembekalan mahasiswa dan dosen pembimbing, dan proses penyiapan kelengkapan mahasiswa PDK), pelaksanaan PDK (proses pengantaran mahasiswa PDK, proses monitoring PDK, proses penarikan mahasiswa PDK, pendampingan dosen pembimbing, pendampingan pembimbing lapangan, unjuk kerja mahasiswa PDK, interaksi mahasiswa PDK, evaluasi proses, dan penilaian proses oleh pembimbing lapangan), proses akhir PDK (penarikan mahasiswa PDK, penyusunan laporan, penyampaian laporan dan penilaian), dan laporan akhir PDK .

Persiapan PDK ditandai dengan penetapan pengelola PDK.Tahapan penetapan pengelola PDK sudah sesuai dengan prosedur yang telah ditetapkan.Pengelola PDK yang telah ditetapkan melakukan persiapan sesuai dengan tahapan dan prosedur yang telah ditetapkan. Hal pertama yang dilakukan oleh pengelola PDK adalah melakukan sosialisasi berupa menyebarkan keterangan pelaksanaan PDK dengan dipasang di papan pengumuman prodi yang terletak di lantai 2 Gedung A. Setelah melakukan sosialisasi kepada mahasiswa perihal pelaksanaan PDK, pengelola PDK melakukan penjajakan tempat PDK berupa 
persuratan dan lobi ke tempat PDK baik langsung oleh pengelola PDK dan atau mahasiswa yang ingin melaksanakan PDK di tempat tersebut.

Pada tahap pendaftaran, mahasiswa mengambil formulir pendaftaran dan menyiapkan persyaratan yang dibutuhkan. Mahasiswa yang sudah memenuhi syarat (lulus mata kuliah Pengetahuan Komputer, Perangkat Lunak Aplikasi dan Etika Profesi Teknik Informatika; lunas semester sebelumnya; sudah regsitrasi semester selanjutnya; ada kartu hasil studi (KHS); ada kartu rencana studi (KRS) dan pas foto) akan diregistrasi sebagai mahasiswa peserta PDK. Mahasiswa yang telah terdaftar akan didistribusikan ke tempat PDK berdasarkan kebutuhan tempat PDK. Proses pendafataran yang dilakukan oleh mahasiswa berdasarkan hasil observasi, wawancara dan dokumentasi sudah berjalan sesuai dengan prosedur dan dianggap berjalan dengan sangat baik.

Mahasiswa yang telah teregistrasi dan telah mendapatkan tempat PDK akan kemudian diberikan pembekalan oleh pengelola. Pembekalan mahasiswa dibagi dalam dua kegiatan, yakni pembekalan umum dilaksanakan di Gedung Merdeka Convention Centre (19 Januari 2019) yang kegiatannya berupa penyampaian materi oleh beberapa narasumber dan pembekalan khusus (18 Januari 2019) yang diberikan oleh dosen pembimbing kepada mahasiswa PDK.Dosen pembimbing diberikan juga pembekalan (17 Januari 2019) yang berkaitan dengan administrasi dan evaluasi PDK.

Pelaksanaan PDK substansinya dihitung mulai pada saat mahasiswa telah berada di tempat PDK dan ketika meninggal tempat PDK. Proses tersebut berisi banyak kegiatan. Berdasarkan hasil observasi dan wawancara, pelaksanaan PDK tahun ini masih sama dengan pelaksanaan PDK tahun-tahun sebelumnya. Pengantaran mahasiswa ke tampat PDK dilaksanakan pada 21-23 Januari 2019. Dari 14 dosen pembimbing, 13 pembimbing melaksanan proses pengantaran mahasiswa PDK ke tempat PDK pada tanggal 21 Januari 2019 dan 1 dosen pembimbing pada tanggal 22 Januari 2019. Ada 1 dosen pembimbing yang tidak bisa melakukan pengantaran dan diganti oleh pengelola PDK yakni mahasiswa PDK yang berlokasi di Kabupaten Luwu. Hasil wawancara menunjukkan bahwa proses pengantaran yang dilakukan oleh dosen pembimbing berjalan dengan lancar. Hasil wawancara dan observasi juga memperlihatkan bahwa tempat PDK menyambut mahasiswa dengan baik dan memberi respon positif pelaksanaan PDK.

Hasil wawancara dengan mahasiswa dan pembimbing lapangan memberikan deskripsi yang jelas bahwa pelaksanaan PDK yang dilakukan oleh mahasiswa yang terhitung sejak mahasiswa mulai praktek di tempat PDK hingga selesai PDK secara umum terlaksana dengan baik.Hasil dari angket untuk pembimbing lapangan memberikan keterangan jelas bahwa mahasiswa PDK menunjukkan kinerja yang baik selama PDK.Adapun angket untuk mahasiswa memperlihatkan fakta bahwa tempat PDK memberikan keleluasaan kepada mahasiswa untuk mengembangkan kognisi, afeksi dan psikomotoriknya dengan baik. Hasil wawancara dengan pembimbing lapangan tentang kinerja mahasiswa yang dibimbingnya juga menunjukkan hal positif bahwa mahasiswa telah melaksanakan PDK dengan sangat baik.

Berdasarkan pada hasil wawancara dan dokumentasi, pelaksanaan monitoring yang dilakukan oleh dosen pembimbing berjalan sesuai waktu yang telah ditetapkan dan sesuai dengan tujuannya.Monitoring dilaksanakan pada tanggal 11-13 Februari 2019. Pun pelaksanaan Penarikan berjalan sesuai waktu yang telah ditetapkan yakni 6-9 Maret 2019. Hasil wawancara menunjukkan bahwa pelaksanaan dosen pembimbing menjemput mahasiswa dari tempat praktek untuik kembali ke kampus berjalan dengan baik.Ada 1 dosen pembimbing dikarenakan sakit, pelaksanaan penjemputan baru dilaksanakan pada tanggal 11 Maret 2019.

Proses pengarahan dosen pembimbing kepada mahasiswa PDK selama pelaksanaan PDK berjalan baik. Komunikasi antara dosen pembimbing dengan mahasiswa terjalin dengan baik. Hasil wawancara dan angket memperlihatkan bahwa kinerja dosen pembimbing sudah sesuai yang diharapkan oleh pengelola.Penyusunan laporan PDK yang dilakukan oleh mahasiswa didampingi dengan baik oleh dosen pembimbing. Hal ini dilihat dari dokumen laporan PDK yang dibuat oleh mahasiswa ditambah dengan dokumen pendukung lainnya.Presentase laporan PDK dilaksanakan oleh mahasiswa didampingi oleh dosen pembimbing difasilitasi oleh pengelola PDK.Pelaksanaan presentase laporan dilaksanakan pada tanggal 16 Maret 2019, setelah pelaksanaan seromonial penyambutan mahasiswa PDK.

Pelaksanaan PDK berakhir dengan penyerahan nilai oleh dosen pembimbing kepada pengelola PDK yang selanjutnya akan dimasukkan di Sistem Informasi Manajemen (SIM). Prosedur yang menyatakan 
bahwa minimal tiga hari setelah pelaksanaan presentase laporan wajib dosen pembimbing menyerahkan nilai akhir PDK kepada pengelola. Berdasarkan hasil wawancara dan dokumen kepada pengelola PDK dan dosen pembimbing bahwa proses pemasukan nilai sudah sesuai waktu dan prosedurnya.

Setelah peng-input-an nilai dilakukan oleh pengelola di Pusat Sistem Informasi Manajemen (SIM), selanjutnya pengelola PDK menyusun laporan.Sistematika laporan disesuaikan dengan format laporan Fakultas Teknik Komputer UNCP.Berdasarkan hasil wawancara dan dokumentasi menunjukkan bahwa pengelola PDK tidak tepat waktu mengumpulkan laporan kepada Fakultas untuk diteruskan kepada pimpinan universitas.Dalam jadwal kegiatan PDK laporan seharusnya selesai pada tanggal 6 April 2019 tetapi baru dituntaskan di akhir bulan Juni.

\section{Aspek Produk}

Komponen penilaian produk meliputi nilai mahasiswa yang datanya didapatkan dari dokumentasi dan penilaian pembimbing lapangan berdasarkan hasil wawancara dan angket.Nilai mahasiswa yang telah mengikuti PDK rata-rata baik dengan distribusi yang mendapat nilai A sebanyak 352 mahasiswa. Nilai B+ ada 10 orang, $B$ ada 1 orang dan $C$ sebanyak 2 orang.Ada beberapa yang mendapat nilai $E$ dikarenakan meraka hanya mendaftar namun tidak mengikuti rangkaian kegiatan PDK.Hasil wawancara dan angket yang diperoleh dari pembimbing lapangan memperlihatkan bahwa mahasiswa yang melaksanakan PDK menunjukkan peningkatan kognisi, afeksi dan psikomotorik yang baik.Untuk lebih detailnya dapat dilihat pada tabel 1 di bawah ini.

Tabel 3. Nilai PDK

\begin{tabular}{|c|c|}
\hline Nilai & Jumlah Mahasiswa \\
\hline A & 352 \\
\hline B + & 10 \\
\hline B & 1 \\
\hline C+ & 2 \\
\hline C & 0 \\
\hline D & 0 \\
\hline E & 4 \\
\hline
\end{tabular}

Pelaksanaan PDK sangat panjang yang dimulai dengan pembentukan pengelola PDK hingga penyerahan laporan akhir, kurang lebih 6 bulan lamanya yakni akhir Oktober 2018 hingga akhir Juni 2019. Oleh mahasiswa (369 mahasiswa), PDK dilaksanakan kurang lebih 7 Minggu yang dimulai dari tanggal 21 Januari 2019 hingga 9 Maret 2019 di 80 instansi pemerintah dan swasta di Luwu Raya (Kotamadya Palopo, Kabupaten Luwu, Kabupaten Luwu Utara dan Kabupaten Luwu Timur). Pelibatan pengelola PDK yang berjumlah 5 orang dan 14 dosen pembimbing menghabiskan anggaran sebesar Rp 72.415.000,-.

Evaluasi konteks membantu merencanakan keputusan, menentukan kebutuhan yang akan dicapai oleh program, dan merumuskan tujuan program. Sedangkan menurut Sukardi (2011: 63), evaluasi konteks menghasilkan informasi tentang macam-macam kebutuhan yang telah diatur prioritasnya, agar tujuan dapat diformulasikan. Daryanto (2007: 88) berpendapat bahwa konteks adalah situasi atau latar belakang yang mempengaruhi jenis-jenis tujuan dan strategi pendidikan yang akan dikembangkan dalam sistem yang bersangkutan, seperti misalnya masalah pendidikan yang dirasakan, keadaan ekonomi negara, pandangan hidup masyarakat dan seterusnya. Evaluasi konteks dari pelaksanaan PDK dari banyak aspek yang diukur seperti tujuan PDK, kesesuaian tujuan PDK dengan visi dan misi institusi, ketersediaan pembimbing, jumlah mahasiswa, ketersediaan sarana belajar mengajar, jadwal perkuliahan, dan konsep kerjasama antara kampus dengan dunia industri memperlihatkan bahwa semua aspek yang diukur tersebut sudah sangat baik.

Tahap kedua dari model CIPP adalah evaluasi masukan. Evaluasi masukan membantu mengatur keputusan, menentukan sumber-sumber yang ada, alternatif apa yang diambil, apa rencana dan strategi untuk mencapai tujuan, bagaimana prosedur kerja untuk mencapainya. Menurut Stufflebeam dalam Widoyoko (2009: 182), pertanyaan yang berkenaan dengan masukan mengarah pada pemecahan masalah yang mendorong diselenggarakannya program yang bersangkutan. Komponen evaluasi masukan meliputi: 1)Sumber daya manusia. 2)Sarana dan peralatan pendukung. 3)Dana atau anggaran. 4)Berbagai prosedur dan aturan yang diperlukan.Evaluasi masukan dari pelaksanaan PDK dari banyak aspek yang diukur seperti 
dalam penelitian ini meliputi kurikulum, prosedur, pengelola PDK, dosen pembimbing, mahasiswa, penentuan waktu dan tempat PDK, sarana dan prasarana, dan dana dan anggaran bahwa semua aspek yang diukur tersebut sudah sangat baik.

Evaluasi proses pada dasarnya diarahkan untuk mengetahui seberapa jauh mana rencana yang telah dilaksanakan di dalam program sudah terlaksana sesuai dengan rencana dan komponen apa yang perlu diperbaiki. Berdasarkan pendapat yang dikemukakan oleh Stufflebeam dan dengan menggunakan komponen-komponen yang terdapat dalam PDK sebagai pertimbangan menentukan aspek yang diukur. Komponen yang sesuai untuk digunakan sebagai komponen indikator evaluasi proses untuk mengevaluasi PDK ialah meliputi proses persiapan PDK (proses pendaftaran PDK, proses pembekalan mahasiswa dan dosen pembimbing, dan proses penyiapan kelengkapan mahasiswa PDK), pelaksanaan PDK (proses pengantaran mahasiswa PDK, proses monitoring PDK, proses penarikan mahasiswa PDK, pendampingan dosen pembimbing, pendampingan pembimbing lapangan, unjuk kerja mahasiswa PDK, interaksi mahasiswa PDK, evaluasi proses, dan penilaian proses oleh pembimbing lapangan), proses akhir PDK (penarikan mahasiswa PDK, penyusunan laporan, penyampaian laporan dan penilaian), dan laporan akhir PDK.

Evaluasi proses dari pelaksanaan PDK dari banyak aspek yang diukur seperti dalam penelitian ini meliputi proses persiapan PDK (proses pendaftaran PDK, proses pembekalan mahasiswa dan dosen pembimbing, dan proses penyiapan kelengkapan mahasiswa PDK), pelaksanaan PDK (proses pengantaran mahasiswa PDK, proses monitoring PDK, proses penarikan mahasiswa PDK, pendampingan dosen pembimbing, pendampingan pembimbing lapangan, unjuk kerja mahasiswa PDK, interaksi mahasiswa PDK, evaluasi proses, dan penilaian proses oleh pembimbing lapangan), proses akhir PDK (penarikan mahasiswa PDK, penyusunan laporan, penyampaian laporan dan penilaian), dan laporan akhir PDK, bahwa semua aspek yang diukur tersebut sudah sangat baik.

Komponen yang sesuai untuk digunakan sebagai komponen indikator evaluasi produk untuk mengevaluasi PDK ialah meliputi nilai akhir dan persepsi pembimbing lapangan terhadap kinerja mahasiswa. Nilai mahasiswa yang telah mengikuti PDK rata-rata baik dengan distribusi yang mendapat nilai A sebanyak 352 mahasiswa. Nilai B+ ada 10 orang, B ada 1 orang dan C sebanyak 2 orang.Ada bebrapa yang mendapat nilai $\mathrm{E}$ dikarenakan meraka hanya mendaftar namun tidak mengikuti rangkaian kegiatan PDK.Hasil wawancara dan angket yang diperoleh dari pembimbing lapangan memperlihatkan bahwa mahasiswa yang melaksanakan PDK menunjukkan peningkatan kognisi, afeksi dan psikomotorik yang baik.

Hasil penelitian dari evaluasi produk di atas sudah sejalan dengan penelitian yang dilaksanakan oleh Zahir (2016) bahwa PDK yang dilaksanakan oleh Fakultas Teknik Komputer diikuti oleh mahasiswa Program Studi Teknik Informatika memberikan sumbangsih positif atau pengaruh dan berkontribusi terhadap pengembangan karakter mahasiswa.

\section{KESIMPULAN}

Evaluasi proses dari pelaksanaan PDK dari banyak aspek yang diukur seperti dalam penelitian ini meliputi proses persiapan PDK (proses pendaftaran PDK, proses pembekalan mahasiswa dan dosen pembimbing, dan proses penyiapan kelengkapan mahasiswa PDK), pelaksanaan PDK (proses pengantaran mahasiswa PDK, proses monitoring PDK, proses penarikan mahasiswa PDK, pendampingan dosen pembimbing, pendampingan pembimbing lapangan, unjuk kerja mahasiswa PDK, interaksi mahasiswa PDK, evaluasi proses, dan penilaian proses oleh pembimbing lapangan), proses akhir PDK (penarikan mahasiswa PDK, penyusunan laporan, penyampaian laporan dan penilaian), dan laporan akhir PDK bahwa semua aspek yang diukur tersebut sudah sangat baik.

Evaluasi produk dari pelaksanaan PDK diukur dari nilai mahasiswa dan persepsi pembimbing lapangan. Nilai mahasiswa yang telah mengikuti PDK rata-rata baik dengan distribusi yang mendapat nilai A sebanyak 352 mahasiswa. Nilai B+ ada 10 orang, B ada 1 orang dan C sebanyak 2 orang.Ada bebrapa yang mendapat nilai $\mathrm{E}$ dikarenakan meraka hanya mendaftar namun tidak mengikuti rangkaian kegiatan PDK dan mahasiswa yang melaksanakan PDK menunjukkan peningkatan kognisi, afeksi dan psikomotorik yang baik. 


\section{DAFTAR PUSTAKA}

Arikunto, Suharsimi \& Safruddin, Cepi, Abdul Jabar. (2009). Evaluasi Program Pendidikan. Jakarta: Bumi Aksara.

Arikunto, Suharsimi \& Abdul Jabar. (2008). Evaluasi Program Pendidikan. Jakarta: Bumi Aksara.

Brinkerhoff, R.O., et.al, (1983). Program evaluation: A practitioner"s guide for trainers and educators. Western Michigan: Kluwer-Nijhoff.

Daryanto. (2007). Evaluasi Pendidikan. Jakarta: Rineka Cipta.

Gronlund, N. E., \& Robert, L. L. (1990). Measurement and evaluation in teaching (6th ed.). New York: Macmillan

Kamil, Mustofa. (2010). Model Pendidikan dan Pelatihan. Bandung: Alfabeta.

Sukardi. (2011). Evaluasi Pendidikan: Prinsip Dan Operasionalnya. Jakarta: Bumi Aksara.

Tayibnapis, Farida Yusuf. (2008). Evaluasi Program dan Instrumen Evaluasi. Jakarta: Rineka Cipta.

Widoyoko, Eko Putro. (2010). Evaluasi Program Pembelajaran. Yogyakarta: Pustaka Pelajar.

Zahir, A. (2016). Pengembangan Karakter Mahasiswa Melalui Praktek Dunia Kerja. Prosiding Seminar Nasional Universitas Cokroaminoto Palopo 2016 (p. 627-636). Palopo: UNCP Press.

\section{Sumber Jurnal}

Mahmudi,Ihwan. (2011). “CIPP: Suatu Model Evaluasi Program Pendidikan”. Jurnal At-Ta'dib. Vol. $6(1)$

Mohebbia, Nooshin.Akhlaghib,Faezeh.Yarmohammadianc ,Mohammad Hossein. Khoshgamd ,Masumeh. (2011). "Application of CIPP model for evaluating the medical records education course at master of science level at Iranian medical sciences universities". Procedia Social and Behavioral Sciences. Vol.15, hal : 3286-3290 Owen, John M. 1993. Program Evaluasi: Forms and Approaches. St. Leonards: Allen \& Unwin Pty Ltd.

Mutrofin.(2010). Evaluasi Program Teks Pilihan untuk Pemula. Yogyakarta: Laksbang Pressindo.

Phattharayuttawat, dkk.(2009). "An evaluation of the curriculum of a graduate programme in clinical psychology".Journal of Medical Educatio.Vol. 3 no. 1.

Sukajaya, I Nyoman.(2010). "Evaluasi Pelaksanaan Kurikulum Teknologi Informasi dan Komunikasi di Jenjang SMAN di Kota Singaraja".Jurnal Pendidikan dan Pengajaran. Jilid 43 (1) : hlm 1 - 72 